\title{
Development of Key Competencies in Integrated Teaching Workplaces
}

\author{
Daniel Kučerka*
}

\begin{abstract}
This article deals with the determination and definition of competencies of pupils and their development in an integrated didactic work place. The article focuses on the practical teaching in the turning workshop at secondary school. The development of competencies is based on the learning objectives for the subject "Technology of Turning" in the practical teaching. The general learning objectives are further specified in sub-objectives, in which the various competencies the student should acquire and develop are defined.
\end{abstract}

Key words: key competencies, integrated teaching workplace, turning.

\section{Introduction}

Integrated didactic departments ensure the development of skills and experiences based on the theoretical knowledge of pupils as acquired during theoretical teaching. In general employers already require qualified professionals with practical workplace experience at the time of recruitment. Those schools that are able to establish practical training programmes in companies give their students an advantage on the labour market. Such programmes provide students with experience under full operating conditions, and under the guidance of practitioners. There are companies that have built multi-functional integrated workplaces, in a similar vein to a school workshop, directly within their company. The us competencies the students acquire can therefore easily be put into practice because the company prepares them accordingly and usually creates jobs for the competent students. The qualified graduate, when they start working full time, therefore knows the working conditions and the requirements of their employer. The reverse is also true, the employer knows the core competencies of their employee.

\footnotetext{
* Daniel Kučerka, The Institute of Technology and Business in České Budějovice, Czech Republic; kucerka@mail.vstecb.cz
} 


\section{Acta Technologica Dubnicae \\ volume 6, 2016, issue 1}

\section{Key competencies}

Competence is the ability to activate and apply the internalisation system of knowledge, skills, vocational, personal and social skills, values, attitudes, as well as other personal qualities, which are specifically configured (level of intensity, the ratio of the components, method of grouping, hierarchy). Competencies may be activated or manifest themselves in different contexts through the activities that a person undertakes in real life.

According to Hrmo and Turek (2003), competence is a behaviour (action or a set of actions) that is characterized by excellent performance in any field of activity. Key competencies are the most important competencies of a set of competencies. They are those competencies that are suitable for addressing a wide range of mostly unforeseen problems that allow an individual to successfully cope with rapid changes in their work, personal and/or social life.

By studying and learning at secondary vocational schools. we want to achieve the formation of expertise relating to key competencies and professional competencies. These competencies are influenced by skills, experience, knowledge, attitudes and orientations in the branch.

Key competencies represent a summary of knowledge, skills, abilities, attitudes and values important for the development of each member of society. The selection of key competencies is based on the values generally accepted in the society and generally connected ideas about the fact which of the competencies contribute to individual's education, happy and successful life, to strengthen the functions of civil society (Veteška \& Tureckiová, 2008).

According to Hrmo and Turek (2003) the competence has the following characteristics:

- it has the activity character,

- it is the quite complex,

- it has the processual character,

- it is dynamic and developed on a various level,

- it is a prerequisite for the development of a person in a particular activity,

- it is the result of formal and informal education.

Experts agree that the key competencies should be acquired by all the pupils during their compulsory education. Whether it is formal or non-formal education, their development is needed throughout their life. To ensure that there is effective acquisition of key competencies, there is especially needed the fundamental change in the content and teaching methods and strategies towards 


\section{Acta Technologica Dubnicae \\ volume 6, 2016, issue 1}

the participative, interactive, experiential learning, which is based on experience and is linked with life.

Competence has the certain behavior, manifested by certain characteristics. These characteristics reflect specific action, but also behaviour, knowledge, skills, motives and performance of an entity in a particular activity. This comes from the combination of characteristics of Hrmo and Turek (2003) and tab. 1 of Veteška (2010).

According to the above mentioned, the competence is defined firstly by a certain standard. This standard assumes a level of mastering the required performance. The performance is determined by a set of performance criteria. By these criteria, it is possible to measure and evaluate the required competencies for example in integrated teaching workplaces. The pupil in every year of his/her study must have certain knowledge, skills, habits and routines. Considering the practical training of the second year the pupil for example by machining on a lathe must handle operations such as alignment of the front part, removing material using the average of the components, grooving, drilling, etc. The third year student is required to handle threading, turning conical parts, turning the copier and so on.

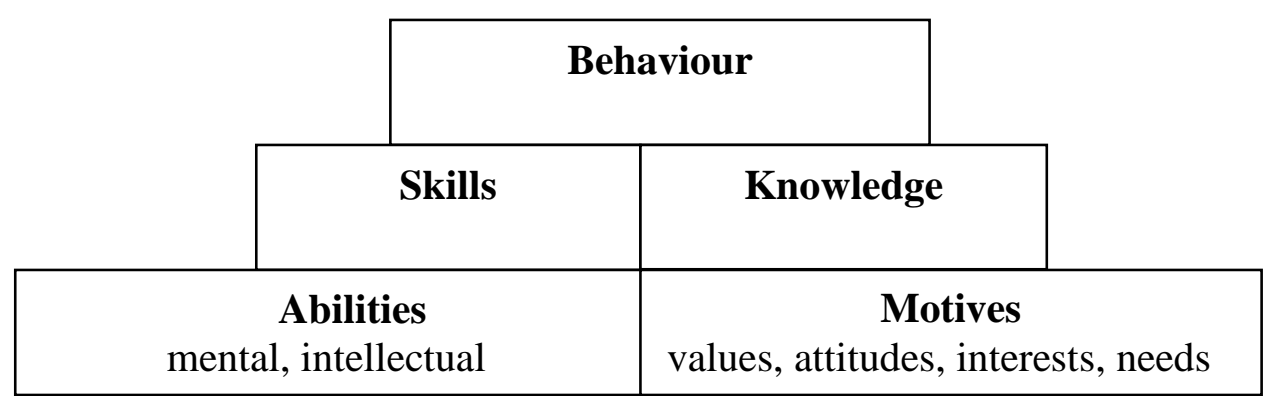

Figure 1. Content of competence (Veteška, 2010).

Veteška (2010) according to Figure 2 provides a graphical representation of key competencies and relationships among qualifications, competencies and education. 


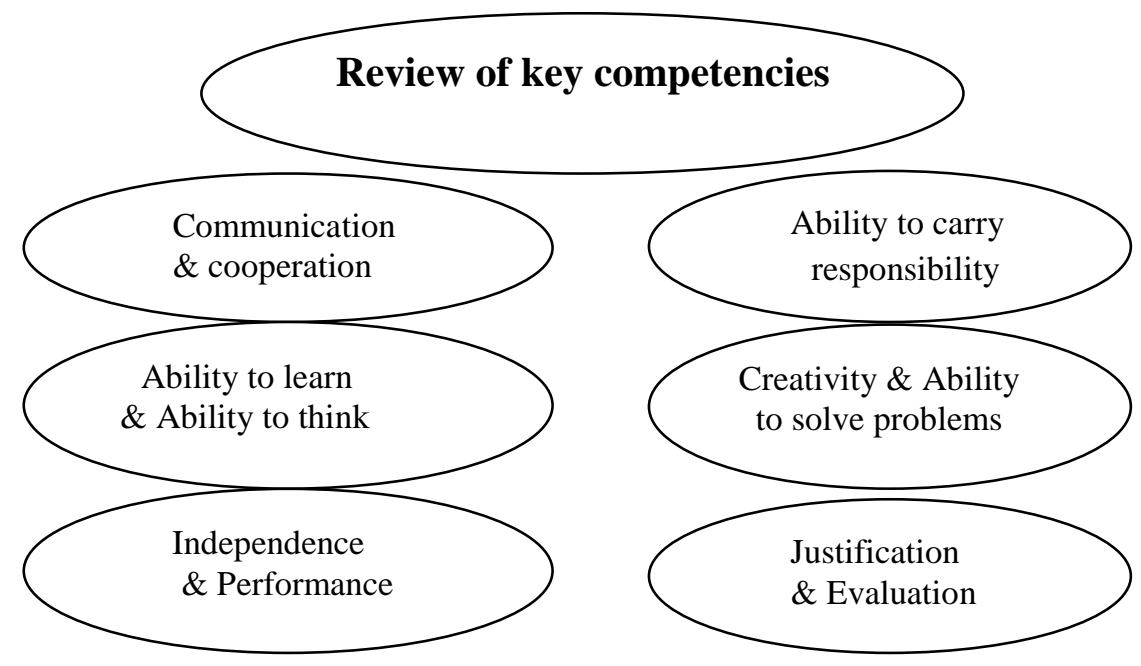

Figure 2. Review of key competencies (Veteška 2010).

Discussion about the need to establish key competencies into the national educational programme and school curriculum, strategic documents, as well as the common use of the term within the European Union is closed. Nobody doubts about the necessity of introducing this terminology.

The development of key competencies is related not only to the education in the primary sense, but also in the lifelong learning, continuing education and retraining.

\section{Integrated teaching departments}

Integrated teaching facilities form a part of Engineering Education. Engineering Education is the interdisciplinary discipline that transforms the knowledge of pedagogy and psychology into technical sciences. Its purpose is to increase the effectiveness of didactic education of engineers involved in the formation and training of future professionals. The role of integrated teaching working places is to bring theory into practice. It means that the student (pupil) during his education has the opportunity to test his theoretical knowledge in practice. For these reasons, such teaching accumulates within more hours.

To develop the integrated working places, it is necessary to take into account the principles such as the light intensity, noise intensity, heat intensity, paint of rooms. In these working places should be taken into consideration the volume of the room for a person in terms of the health protection principles and ergonomics. In terms of equipment it is required to ensure so that people should 


\section{Acta Technologica Dubnicae \\ volume 6, 2016, issue 1}

work on didactic machines with the valid revision and these machines should have the right (safe) instruments, tools and accessories.

Integrated learning workplace is understood as a set of suitable formulated didactic material resources required for the enquired type mainly of training classrooms (Hrmo, Kučerka, \& Krištofiaková, 2014).

The integrated teaching departments include: language classrooms (laboratories), video centre, computer and multimedia classroom, classroom associated with the study room, specialized classrooms for programming of machine tools, etc.

In my opinion, it is possible to divide the integrated teaching departments in the following groups:

- school workshops at secondary schools

- $\quad$ special departments for gifted pupils

- $\quad$ special integrated workplaces for disabled students

- laboratories,

- special classrooms of vocational subjects.

School workshops of secondary schools can be divided into:

- workshop of manual machining,

- workshop of machining and

- workshops of CNC machines.

Machining workshops consist of workshops of lathes (Figure 3), milling machines (Figure 4), grinders, drill machines or some machines for finishing operations.

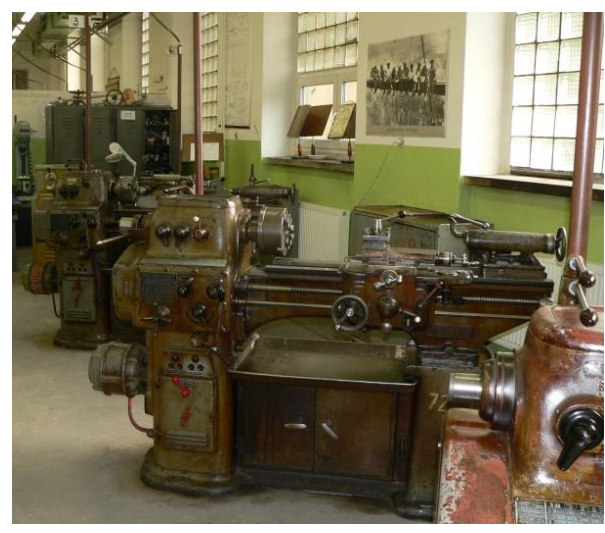

Figure 3. Turning workshop.

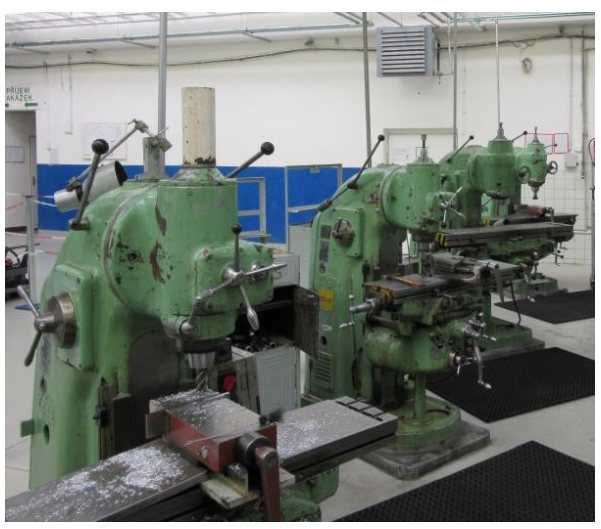

Figure 4. Milling workshop. 
Turning workshop consists of various types of lathes. The basic type is the lathe SV $18 \mathrm{R}$, which is usually in every workshop. From a didactic point of view these are the teaching tools that are the real teaching aids where the pupils learn to work. They acquire the knowledge from the teaching theory and use them in practice and gain experience, skills and habits. These are actually the key competencies.

\section{Development of key competencies in integrated teaching departments - machining workshops}

The development of pupils' key competencies in an integrated teaching workplace affects the lesson planning a teacher is acquired to do. This process is an extremely important component of planning competencies and teaching abilities. Teacher with his/her experience and interest in his/her job is able in his/her preparation for the the lesson during his/her planning process answer many important questions. First of all, he/she has to find answers to questions:

- What do I want to achieve during the lessons but also in all thematic units?

- What do I want the students to know?

- What skills the students should have?

- What are the cross-curricular relations in the topic?

- What information do I choose and how can I continue the already acquired knowledge of students?

- What homework or project will I give to them?

The answer to these questions for the teacher is his/her plan. In this plan there are the answers for the achievement of learning objectives through the content, methods and material and immaterial resources.

Learning objectives can be organized into a hierarchy according to the concreteness or abstractness of general objectives, targets and specific objectives. As the example we can mention the teaching objectives of the subject Practical training - thematic unit Turning.

General objective of the unit:

To master basic concepts, methods and practical activities in turning.

Interim Destination of the thematic unit Turning

- to know basic concepts and the geometry of the cutting tool (turning knife),

- to know basic types of machining on a lathe (turning of cylindrical surfaces, align of the front parting, grooving etc.),

- to understand the nature and acquire the basic skills turnings.

Specific objectives of the thematic unit Turning:

- to define and explain the essence of cultivation. 


\section{Acta Technologica Dubnicae \\ volume 6, 2016, issue 1}

- to name and draw the basic angles of cutting tools (lathe knives)

- to appoint the types of turning blades and describe their geometry,

- to appoint the types lathe

- to list some of the lathe,

- to learn to control lathes,

- to be able to perform a desired lathe operation.

Mastering the individual goals during the practical training on the lathe are the own key competencies of the student. The acquired habits, skills, experience and attitudes are important for his professional experience, or they form the basis for dealing with $\mathrm{CNC}$ lathes.

\section{Conclusion}

Students, through their studies at secondary school, are seeking to acquire the necessary key competencies and professional competencies to qualify in their field. These competencies are influenced by skills, experience, knowledge, abilities and attitudes that are oriented to this branch.

Required competencies are formed in pupils by a range of professionals (secondary school teachers) in the theoretical and practical teaching from different specializations. Students in addition to vocational subjects also have a general educational subjects which are the support subjects of future specialist.

In integrated teaching workplaces the students gain their practical experience and skills. Their development is dependent on the preparation, it affects the planning of a lesson by the teacher. This process is an extremely important component of planning skills and teaching skills. Equally important component is the use and inclusion of appropriate teaching resources to teaching which include the teaching machines, equipment, tools and the accessories.

\section{Acknowledgement}

The authors gratefully acknowledge the contribution of the KEGA Grant Agency of the Slovak Republic under the KEGA Project 010UCM---4/2015. 


\section{References}

Hrmo, R., \& Turek, I. (2003). Klúčové kompetencie I. Bratislava: STU.

Hrmo, R., Kučerka, D., \& Krištofiaková, L. (2014). Integrované didaktické pracoviská a ich využitie. In 10. medzinárodná vedecká konferencia, SCHOLA 2014. Inovácie vo výchove a vzdelávaní - Trendy v odborovej didaktike (pp. 142-158). Dubnica nad Váhom: Dubnický technologický inštitút v Dubnici nad Váhom.

Veteška, J. (2010). Kompetence ve vzděláváni dospělých. Praha: UJAK.

Veteška, J., \& Tureckiová, M. (2008). Vzděláváni a rozvoj podle kompetencí. Praha: UJAK. 